with its analogues and metabolites) all fall into this group. The results of three prospective controlled trials have now appeared, in which treated subjects in their first menopausal decade were compared with matched controls. ${ }^{14-16}$ All found that treatment with oestrogens (with testosterone added in one trial $^{14}$ ) eliminated the measured $1-4 \%$ annual losses observed in the controls. Lindsay et $a l^{17}$ have since published the results of a small prospective study which suggest that progestogens may be as effective as oestrogens, whereas the Leeds $^{16}$ and Nebraska ${ }^{14}$ trials included groups treated with calcium supplements alone. These lost bone at rates intermediate between the controls and those receiving oestrogens.

Normally calcium absorption is inhibited by a high-calcium diet, but at least some of the extra dietary calcium must be absorbed. Indeed, in the Nebraska study urine calcium concentrations rose by a mean of $1 \mathrm{mmol}$ day. Older women, however, absorb calcium less effectively, ${ }^{3}$ and this has provided the rationale for giving vitamin $\mathrm{D}$ and its analogues. Pharmacological doses of vitamin $\mathrm{D}$ are often required to achieve a measurable effect in this age group, ${ }^{3}$ whereas when synthetic $1 \propto(\mathrm{OH}) \mathrm{D}_{3}$ is used (which the liver hydroxylates to the active metabolite $1,25(\mathrm{OH})_{2} \quad D_{3}$ ) doses of only 1 or $2 \mu \mathrm{g}$ per day are effective in raising calcium absorption. Unfortunately, hypercalcaemia may occur at these doses, ${ }^{1819}$ and much of the extra calcium absorbed finds its way into the urine.

Clearly, then, bone loss may be delayed or prevented by prophylactic use of oestrogens or calcium supplements. What are the risks of such treatment? In the case of oestrogens the principal risk is possibly endometrial carcinoma, although the size of the risk remains to be defined. ${ }^{20}$ The risk of taking calcium supplements is small; from Nordin's data ${ }^{21}$ the rise in urine calcium with calcium supplements could be predicted to lead to a $10-20^{\circ}$ increase in the (low) incidence of renal stones. Nevertheless, since both agents at their recommended doses reduce bone turnover, both would be expected to lead to a more completely calcified skeleton; and the relative gain in bone mass might yet prove to be at the expense of the quality of the bone.

The alternative approach is to attempt to restore the skeletal mass after decline has occurred. To achieve results within a reasonable time the first requirement is to stimulate bone formation. Three agents have shown promise: fluoride, growth hormone, and the human synthetic parathyroid hormone fragment hPTH (1-34). All three agents stimulate the formation of new bone-forming cells, and fluoride may additionally inhibit resorption. Initial experience with fluoride was disappointing, since the formation of excess osteoid was observed. ${ }^{12}$ Encouraging reports of studies in which vitamin $\mathrm{D}$ and calcium supplements were added ${ }^{12} 2223$ have since appeared, but further experience is awaited.

Growth hormone ${ }^{24}$ and hPTH $(1-34)^{25}$ both appreciably increased bone turnover, but the average calcium balance changed little. On general grounds hPTH (1-34) is preferable: at low doses it does not produce hypercalcaemia and it should be free from other side effects. Nevertheless, it remains to be seen whether the osteoclastic response to hPTH can be reduced by modifying the dose or by combining it with an antiosteoclastic agent.

Nothing has yet been shown to reverse involutional osteoporosis, while prophylactic oestrogens and calcium supplements must still be shown to reduce the fracture rate. Meanwhile we need to establish the size and characteristics of the group of individuals at risk so they may be identified before they develop fractures. If we find that patients have to be supervised closely, we shall then have to assess the practica- bility of large-scale prophylaxis in the light of future progress in treating established osteoporosis by agents stimulating bone formation. Clearly the research effort being expended on these questions is fully justified by the size of the problem: the w SW Thames region alone continuously fills the equivalent 3 of a 250-bedded hospital with patients with fractured neck $\stackrel{\mathbb{D}}{\square}$ of the femur ${ }^{26}$ and the annual cost of this single injury in $\subseteq$ Europe and North America in 1978 will exceed US $\$ 2000 \mathrm{~m}$. $\overrightarrow{\vec{N}}$

${ }^{1}$ Albright, F, Smith, P H, and Richardson, A M, fournal of the American Medical Association, 1941, 116, 2465.

2 Nilsson, B E, Clinical Orthopaedics and Related Research, 1970, 68, 93.

${ }^{3}$ Nordin, B E C, et al, Calcified Tissue Research, 1976, 21, suppl, 442.

${ }^{4}$ Linkswiler, H M, Joyce, C L, and Anand, C R, Transactions of the Nerc York Academy of Sciences, 1974, 36, 333

5 Thompson, D L, and Frame, B, Annals of Internal Medicine, 1976, 85, 789. $\overrightarrow{0}$

${ }^{6}$ Currey, J D, and Butler, G, Fournal of Bone and foint Surgery, 1975, 57A, 810

7 Solomon, L, Lancet, 1978, in press.

${ }^{8}$ Cohn, S H, et al, Fournal of Nuclear Medicine, 1974, 15, 428.

${ }^{9}$ Marshall, J H, et al, Health Physics, 1973, 24, 125.

10 Reeve, J, Hesp, R, and Wootton, R, Calcified Tissue Research, 1977, 22, suppl, 311.

${ }^{11}$ Meunier, P, et al, Clinics in Endocrinology and Metabolism, 1973, 2, 239. $\overrightarrow{\mathrm{N}}$

12 Riggs, B L, et al, Clinics in Endocrinology and Metabolism, 1973, 2, 317.

${ }^{13}$ Harrison, J E, et al, Metabolism, 1971, 20, 1107.

${ }^{4}$ Recker, R R, Saville, P D, and Heaney, R P, Annals of Internal Medicine, $1977,87,649$.

${ }^{15}$ Lindsay, R, et al, Lancet, 1976, 1, 1038

${ }^{16}$ Horsman, A, et al, British Medical fournal, 1977, 2, 789.

${ }^{17}$ Lindsay, R, et al, Clinical Science and Molecular Medicine, 1978, 54, 193. 으

${ }^{8}$ Marshall, D H, and Nordin, B E C, Clinical Endocrinology, 1977, 7, 159S.

19 Sorensen, O H, et al, Clinical Endocrinology, 1977, 7, 169S.

${ }^{20}$ Doll, R, et al, Lancet, 1977, 1, 745.

${ }^{21}$ Nordin, B E C, Clinical Science and Molecular Medicine, 1977, 52, 1.

22 Parsons, V, et al, Calcified Tissue Research, 1977, 22, suppl, 236.

${ }^{23}$ Meunier, $\mathbf{P}$ J, et al, presented to the 2nd CEMO Symposium "Fluoride and Bone", Nyon, Switzerland, October 1977.

${ }^{24}$ Haas, H G, et al, Calcified Tissue Research, 1976, 21, suppl, 467.

${ }^{25}$ Reeve, J, et al, in Proceedings of the 6th Parathyroid Conference, eds D $\mathrm{H}$ Copp and R V Talmage, p 71. Amsterdam, Excerpta Medica, 1978

${ }^{26}$ Gallannaugh, S C, Martin, A, and Millard, P H, British Medical fournal, 음 1976, 2, 1496

\section{Varicocele and subfertility}

In 1550 Ambroise Paré aptly described varicocele as "a compact pack of vessels quite filled with melancholic blood." Over the years the condition attracted scant attention: it was 은 attributed to inadequate sexual relief, and late marriage was $\underset{\sim}{\sim}$ considered a strong predisposing factor. In 1889 Bennett $^{1}$ o described a technique for its radical cure and commented "in many cases secretion of spermatozoa is arrested." Nevertheless, little notice was taken of the possible deleterious effects $N$ of a varicocele on fertility until 1952, when Tulloch ${ }^{2}$ reported the return of normal spermatogenesis after ligation of the lesion in an azoospermic man, who subsequently fathered a child. Three years later he reported the results of treatment in $\stackrel{\mathscr{D}}{?}$ 30 subfertile men who had had ligation of varicocele, five 0 bilaterally: 20 showed a significant improvement in the sperm $\stackrel{0}{\mathbb{D}}$ count and 10 became fathers. Numerous reports ${ }^{4-9}$ since then $\stackrel{\mathbb{P}}{\mathcal{P}}$ have confirmed that the sperm count will improve after $\mathbb{Q}$ operation in about two-thirds of these patients.

Varicocele is common: Johnson and colleagues ${ }^{10}$ found 1518 among 1592 normal US Air Force recruits aged between 17 and $24 ; 94$ of these men produced semen samples, of which 흘 $56^{\circ}$ \% showed reduced motility and $27^{\circ}$ o low sperm counts. $\stackrel{P}{?}$ Varicocele is much more common among men attending subfertility clinics, where the reported incidence varies between $19^{11}$ and $39^{\circ}{ }_{0} \cdot{ }^{12}$ Retrograde caval venography ${ }^{1314}$ has 
shown that the basic abnormality is reversed blood flow due to incompetence of valves in the internal spermatic vein, nearly always on the left side. This results in pooling of blood around the testicles and an increased scrotal temperature, the extent of which depends on the size of the varicocele. ${ }^{15}$ Spermatogenesis is depressed on both sides, ${ }^{16}$ probably as a direct result of the increased temperature rather than of reflux of adrenal metabolites. ${ }^{71718}$ Typically seminal analysis shows a depressed sperm count, with poor motility and an increased percentage of abnormal forms. ${ }^{19}$

Clinically the condition may be diagnosed by careful examination with the patient standing in good light. Small varicoceles are shown up by the Valsalva manoeuvre; they are important, since fertility may be improved just as much after ligation of a small as of a large one. ${ }^{2021}$ This finding has led to a search for varicoceles that are not detected on routine examination but suspected as a result of decreased left testicular firmness or increased venous pressure during a Valsalva manoeuvre. Comhaire et al ${ }^{22}$ carried out scrotal thermography in 36 men suspected of having subclinical varicocele and the results were abnormal in 19 ; in 16 of these patients venography confirmed reflux in the spermatic vein. The simple non-invasive technique of thermography, widely available for early diagnosis of cancer of the breast, appears to offer a valuable screening test for minor or subclinical varicocele, and this test is also useful for postoperative assessment of cases with a few residual veins.

Varicocele may be corrected operatively by the suprainguinal, ${ }^{23}$ inguinal, ${ }^{24}$ or scrotal approach, ${ }^{6}$ and each route has its advocates. The inguinal approach is probably the simplest, since the enlarged veins unite at the internal ring, and both the internal spermatic vein and any secondary varicosity in the cremasteric venous system ${ }^{25}$ can be dealt with simultaneously. The suprainguinal approach suffers from the disadvantage that the secondary cremasteric incompetence may be missed, and the scrotal approach is associated with a small but definite incidence of testicular atrophy. ${ }^{26}$ Most varicoceles affect only the left side; bilateral varicoceles have been reported in $15 \%$ of cases, but the right side was affected alone in only $0.6 \%$ of cases. ${ }^{27}$

The results of surgery are good. In a recent analysis of 986 cases Dubin and Amelar ${ }^{27}$ described improvement in the quality of the semen in $70 \%$, and $53 \%$ of the patients' wives became pregnant. The results were better for patients who had had preoperative sperm counts of over 10 million $\mathrm{ml}(85 \%$ semen quality improved, $70 \%$ pregnancy rate) than for patients who had preoperative counts of less than 10 million $(35 \%$ improved, $27 \%$ pregnancy rate). The results in the latter group were improved by the empirical use of postoperative human chorionic gonadotrophin $\left(55^{\circ}\right.$ improved, $45 \%$ pregnancy rate). These results are exceptionally good, and the high pregnancy rate implies that the operation on the varicocele was only one incident in the integrated management of both marital partners.

${ }^{1}$ Bennett, W H, Lancet, 1889, 1, 261.

2 Tulloch, W S, Edinburgh Medical fournal, 1952, 59, No 3, pt 2, p 29

3 Tulloch, W S, British Medical fournal, 1955, 2, 356.

4 Davidson, H A, Practitioner, 1954, 173, 703.

${ }^{5}$ Scott, L S, and Young, D, Fertility and Sterility, 1962, 13, 325

${ }^{6}$ Hanley, H G, and Harrison, R G, British fournal of Surgery, 1962, 50, 64.

'Charney, C W, and Baum, S, fournal of the American Medical Association, 1968, 204, 1165

${ }^{8}$ MacLeod, J, Fertility and Sterility, 1969, 20, 545.

9 Brown, J S, Fertility and Sterility, 1976, 27, 1046

10 Johnson, D E, Pohl, D R, and Rivera-Correa, H, Southern Medical fournal, 1970, 63, 34 .

11 Davis, J E, et al, International fournal of Fertility, 1965, 10, 359.

12 Dubin, L, and Amelar, R D, Fertility and Sterility, 1971, 22, 469.
13 Ahlberg, N E, et al, Acta Radiologica (Diagnosis), 1966, 4, 517.

${ }^{14}$ Brown, J S, Dubin, L, and Hotchkiss, R S, Fertility and Sterility, 1967, $18,46$.

15 Kormano, M, et al, Fertility and Sterility, 1970, 21, 558.

${ }_{16}$ Dubin, L, and Hotchkiss, R S, Fertility and Sterility, 1969, 20, 51.

17 Agger, P, Fertility and Sterility, 1971, 22, 270.

${ }^{18}$ Lindholmer, C, Thulin, L, and Eliasson, R, Andrologie, 1973, 5, 21.

${ }^{19}$ MacLeod, J, Fertility and Sterility, 1965, 16, 735.

"20 Kiszka, E F, and Cowart, G T, fournal of Urology, 1960, 83, 713.

${ }^{21}$ Dubin, L, and Amelar, R D, Fertility and Sterility, 1970, 21, 606.

${ }^{22}$ Comhaire, F, Monteyne, R, and Kunnen, M, Fertility and Sterility, 1976, 27, 694.

${ }^{23}$ Palomo, A, Fournal of Urology, 1949, 61, 604.

24 Ivanissevich, O, Fournal of the International College of Surgeons, 1960, 34, 742.

${ }^{25}$ Hendry, W F, et al, British fournal of Urology, 1973, 45, 684.

${ }^{26}$ Fritjofsson, A, et al, Acta Chirurgica Scandinavica, 1966, 132, 200.

${ }^{27}$ Dubin, L, and Amelar, R D, Urology, 1977, 10, 446.

\section{Phased justice?}

A trusting doctor might concede the Review Body's eighth report ( $\mathrm{p}$ 1360) to be phased justice. But how many trusting doctors are there left? A decade or more of Government interference in the profession's independent machinery for pay review has made the average doctor suspicious. Since August 1975 suspicions have not been lessened by pay restrictions and taxation policies that have struck savagely, and often unfairly, at doctors' take-home incomes, seriously distorting pay relativities within the profession. The Review Body made its views quite clear in last year's report. ${ }^{1}$ This year it has done so again: "It is the failure to take account of the need to correct these injustices that, in our view, is the principal cause for the decline in the morale of the medical and dental professions over the last three years. We have said beforeand we repeat now, because the position has undoubtedly worsened-that, if this decline is not reversed, the consequences for the National Health Service and for the community as a whole will become increasingly serious."

The profession has previously urged the Review Body to publish recommendations on what size award NHS doctors should receive, disregarding government norms. ${ }^{2}$ Until now the Review Body has eschewed the idea. This time it creates a welcome precedent by publishing two sets of recommendations: one giving "fully up-to-date" levels of pay at 1 April, restoring what it sees as the "proper relationship" of doctors" rewards with those of other occupations; and the other the amount to be paid on 1 April 1978, which is within the Government's $10 \%$ guidelines. The Review Body acknowledges the importance of the Government's pay policy and proposes that the $£ 135 \mathrm{~m}$ difference between the two sets of recommendations should be paid in two phases-April 1979 and April 1980.

Sir Ernest Woodroofe and his colleagues are not naive and presumably they view their work as of value to both doctors and patients or they would have resigned their thankless task long ago. In their eighth major review they confronted a delicate political dilemma, made no easier by their forthright support of the doctors' case last year. ${ }^{13}$ Had they dutifully toed the Government line and proposed a simple $10 \%$, the profession would have lost all faith in their independence. Had they recommended $30^{\circ}$, now to bring doctors' pay up to date, the Government would have rejected it out of hand. But as the Cabinet had already issued promissory notes to the firemen, policemen, and the military it would have been extremely difficult for ministers to refuse a similar deal for NHS doctors. So the Review Body recommended accordingly. 